\title{
Sources and Consequences of Groundwater Contamination
}

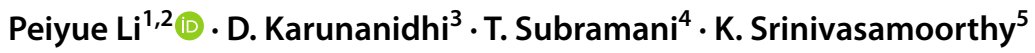

Accepted: 17 December 2020 / Published online: 2 January 2021

(c) The Author(s), under exclusive licence to Springer Science+Business Media, LLC part of Springer Nature 2021

\begin{abstract}
Groundwater contamination is a global problem that has a significant impact on human health and ecological services. Studies reported in this special issue focus on contaminants in groundwater of geogenic and anthropogenic origin distributed over a wide geographic range, with contributions from researchers studying groundwater contamination in India, China, Pakistan, Turkey, Ethiopia, and Nigeria. Thus, this special issue reports on the latest research conducted in the eastern hemisphere on the sources and scale of groundwater contamination and the consequences for human health and the environment, as well as technologies for removing selected contaminants from groundwater. In this article, the state of the science on groundwater contamination is reviewed, and the papers published in this special issue are summarized in terms of their contributions to the literature. Finally, some key issues for advancing research on groundwater contamination are proposed.
\end{abstract}

Groundwater is a major source of fresh water for the global population and is used for domestic, agricultural, and industrial uses. Approximately one third of the global population depends on groundwater for drinking water (International Association of Hydrogeologists 2020). Groundwater is a particularly important resource in arid and semi-arid regions where surface water and precipitation are limited ( $\mathrm{Li}$ et al. 2017a). Securing a safe and renewable supply of groundwater for drinking is one of the crucial drivers of sustainable development for a nation. However, urbanization, agricultural practices, industrial activities, and climate change all pose significant threats to groundwater quality. Contaminants, such as toxic metals, hydrocarbons, trace organic contaminants, pesticides, nanoparticles, microplastics, and

Peiyue Li

lipy2@163.com; peiyueli@chd.edu.cn

1 School of Water and Environment, Chang' an University, No. 126 Yanta Road, Xi' an 710054, Shaanxi, China

2 Key Laboratory of Subsurface Hydrology and Ecological Effects in Arid Region of the Ministry of Education, Chang'an University, No. 126 Yanta Road, Xi' an 710054, Shaanxi, China

3 Department of Civil Engineering, Sri Shakthi Institute of Engineering and Technology (Autonomous), Coimbatore, India

4 Department of Geology, CEG, Anna University, Chennai, India

5 Department of Earth Sciences, Pondicherry University, Kalapet, Pondicherry, India other emerging contaminants, are a threat to human health, ecological services, and sustainable socioeconomic development (Li 2020; Li and Wu 2019).

Over the past three decades, chemical contamination is a common theme reported in groundwater studies. While groundwater contamination is a great challenge to human populations, this subject also presents a great opportunity for researchers to better understand how our subsurface aquifers have evolved and for decision makers to grasp how we can protect both the quality and quantity of these resources. Fresh water aquifers are one of the most important sections of the Critical Zone (CZ), which extends from the top of the vegetation canopy down to the bottom of the aquifer (Lin 2010). As part of the global effort to understand the functions, structures, and processes within the $\mathrm{CZ}$, a range of investigations have been performed that contribute to our knowledge of the circulation and evolution of groundwater (Sawyer et al. 2016; Goldhaber et al. 2014).

Many of the contaminants in groundwater are of geogenic origin as a result of dissolution of the natural mineral deposits within the Earth's crust (Basu et al. 2014; Pandey et al. 2016; Subba Rao et al. 2020; He et al. 2020a). However, due to rapid expansion of the global population, urbanization, industrialization, agricultural production, and the economy, we now are faced with the challenge of the negative impacts of contaminants of anthropogenic origin. The countries most affected by these global changes are those that are going through rapid economic development, with many of them located in the eastern hemisphere (Clement and Meunie 
2010; Hayashi et al. 2013; Lam et al. 2015). Thus, it is appropriate that this special issue entitled, "The fate and consequences of groundwater contamination" focuses on studies of the unique challenges related to contaminants of both anthropogenic and geogenic origin in groundwater in several countries in the eastern hemisphere, including China, India, Turkey, Bangladesh, Ethiopia, and Nigeria. Figure 1 illustrates the countries where the research was conducted and the classes of chemical contaminants reported in the articles in this special issue.

The range of topics included in articles in this special issue includes: (1) Latest methods for detecting and tracking the movement of groundwater contaminants; (2) Novel techniques for assessing risks to human populations consuming contaminated groundwater; (3) Effects of groundwater contamination on the abiotic environment, such as soil, sediments, and surface water; and (4) Case studies and remedial actions to control groundwater contamination from natural and anthropogenic sources. The co-editors of this special issue anticipate that these articles will facilitate an understanding of the origins and extent of groundwater contamination and its consequences and will provide examples of approaches that can be taken for remediation of groundwater contamination and protection of groundwater quality.

\section{Major Contaminants}

Groundwater contamination is defined as the addition of undesirable substances to groundwater caused by human activities (Government of Canada 2017). This can be caused by chemicals, road salt, bacteria, viruses, medications, fertilizers, and fuel. However, groundwater contamination differs from contamination of surface water in that it is invisible and recovery of the resource is difficult at the current level of technology (MacDonald and Kavanaugh 1994). Contaminants in groundwater are usually colorless and odorless. In addition, the negative impacts of contaminated groundwater on human health are chronic and are very difficult to detect (Chakraborti et al. 2015). Once contaminated, remediation is challenging and costly, because groundwater is located in subsurface geological strata and residence times are long (Wang et al. 2020; Su et al. 2020). The natural purification processes for contaminated groundwater can take decades or even hundreds of years, even if the source of contamination is cut off (Tatti et al. 2019).

The numbers of classes of contaminants detected in groundwater are increasing rapidly, but they can be broadly classified into three major types: chemical contaminants, biological contaminants, and radioactive contaminants.

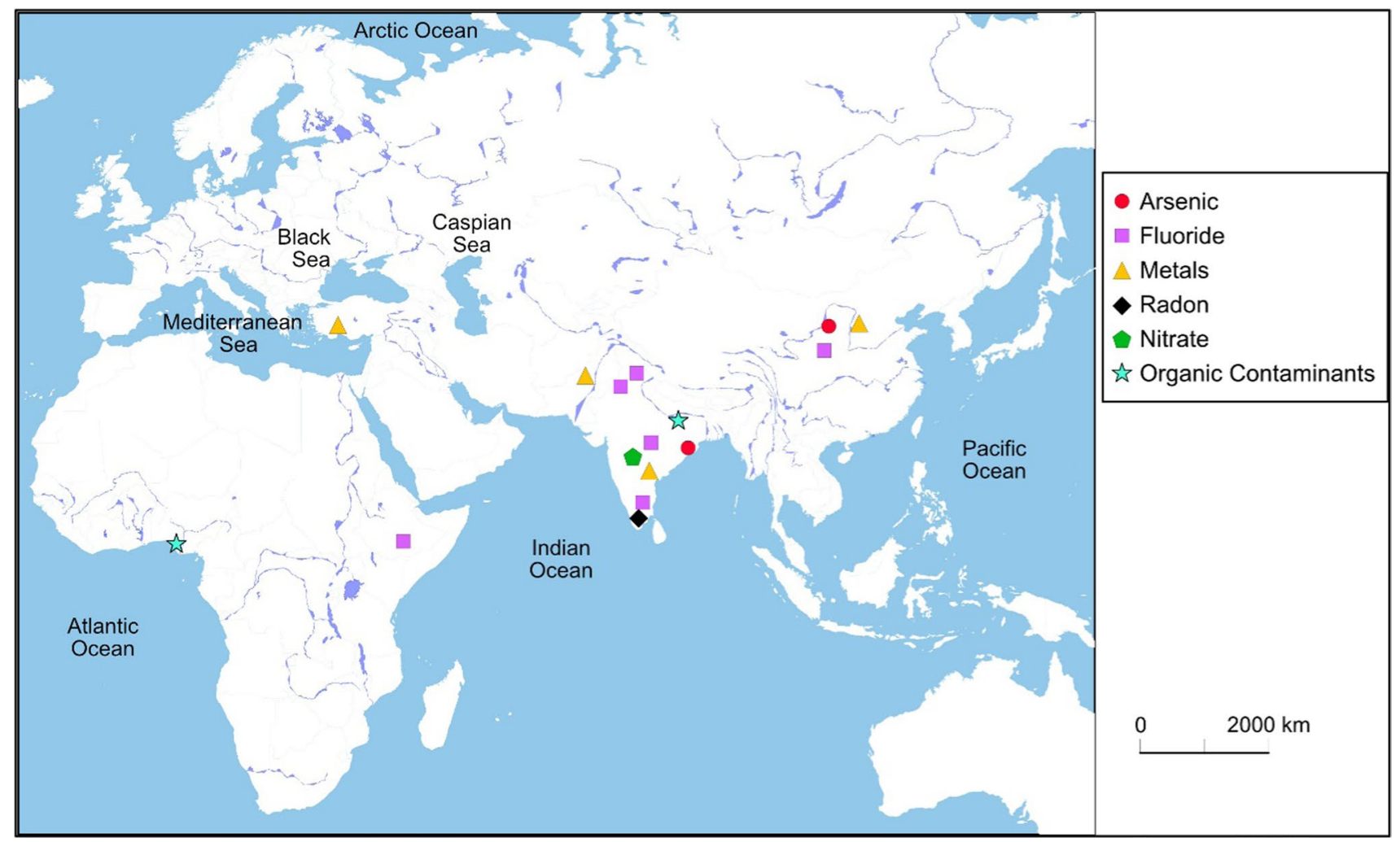

Fig. 1 Eastern hemisphere, showing the countries where the groundwater research was conducted and the classes of contaminants studied in the articles published in this special issue 
These contaminants can come from natural and anthropogenic sources (Elumalai et al. 2020). The natural sources of groundwater contamination include seawater, brackish water, surface waters with poor quality, and mineral deposits. These natural sources may become serious sources of contamination if human activities upset the natural environmental balance, such as depletion of aquifers leading to saltwater intrusion, acid mine drainage as a result of exploitation of mineral resources, and leaching of hazardous chemicals as a result of excessive irrigation (Su et al. 2020; Wu et al. 2015; Li et al. 2016, 2018).

Nitrogen contaminants, such as nitrate, nitrite, and ammonia nitrogen, are prevalent inorganic contaminants. Nitrate is predominantly from anthropogenic sources, including agriculture (i.e., fertilizers, manure) and domestic wastewater (Hansen et al. 2017; He and Wu 2019; He et al. 2019; Karunanidhi et al. 2019; Li et al. 2019a; Serio et al. 2018; Zhang et al. 2018). Groundwater nitrate contamination has been widely reported from regions all over the world. Other common inorganic contaminants found in groundwater include anions and oxyanions, such as $\mathrm{F}^{-}, \mathrm{SO}_{4}{ }^{2-}$, and $\mathrm{Cl}^{-}$, and major cations, such as $\mathrm{Ca}^{2+}$ and $\mathrm{Mg}^{2+}$. Total dissolved solids (TDS), which refers to the total amount of inorganic and organic ligands in water, also may be elevated in groundwater. These contaminants are usually of natural origin, but human activities also can elevate levels in groundwater (Adimalla and $\mathrm{Wu} 2019)$.

Toxic metals and metalloids are a risk factor for the health of both human populations and for the natural environment. Chemical elements widely detected in groundwater include metals, such as zinc $(\mathrm{Zn})$, lead $(\mathrm{Pb})$, mercury $(\mathrm{Hg})$, chromium $(\mathrm{Cr})$, and cadmium $(\mathrm{Cd})$, and metalloids, such as selenium ( $\mathrm{Se}$ ) and arsenic (As). Exposures at high concentrations can lead to severe poisoning, although some of these elements are essential micronutrients at lower doses (Hashim et al. 2011). For example, exposure to hexavalent chromium $\left(\mathrm{Cr}^{6+}\right)$ can increase the risk of cancer $(\mathrm{He}$ and $\mathrm{Li}$ 2020). Arsenic is ranked as a Group 1 human carcinogen by the US Environmental Protection Agency (EPA) and the International Agency for Research on Cancer (IARC), and $\mathrm{As}^{3+}$ can react with sulfhydryl (-SH) groups of proteins and enzymes to upset cellular functions and eventually cause cell death (Abbas et al. 2018; Rebelo and Caldas 2016). Toxic metals in the environment are persistent and subject to moderate bioaccumulation when they enter the food chain $(\mathrm{He}$ and Li 2020; Hashim et al. 2011).

Organic contaminants have been widely detected in drinking water, and many of these compounds are regarded as human carcinogens or endocrine disrupting chemicals. In groundwater, more than 200 organic contaminants have been detected, and this number is still increasing (Lesser et al. 2018; Jurado et al. 2012; Lapworth et al. 2012; Sorensen et al. 2015). Some organic contaminants are biodegradable, while some are persistent. The biodegradable organic contaminants originate mainly from domestic sewage and industrial wastewater. Many of these organic substances are naturally produced from carbohydrates, proteins, fats, and oils and can be transformed into stable inorganic substances by microorganisms. They have no direct toxic effects on living beings but can reduce the dissolved oxygen levels in groundwater. Common organic contaminants include hydrocarbons, halogenated compounds, plasticizers, pesticides, pharmaceuticals, and personal care products and natural estrogens, among others (Lapworth et al. 2015; Meffe and Bustamante 2014). Many of the halogenated compounds (e.g., chlorinated, brominated, fluorinated) are stable in the environment and can be accumulated and enriched in organisms, causing harmful effects in organisms from higher trophic levels, including humans (Gwenzi and Chaukura 2018; Schulze et al. 2019). The persistent organic contaminants are mainly compounds used for agriculture, industrial processes, and protection of human health (Lapworth et al. 2015). Because these compounds degrade very slowly or even not at all, they may permanently threaten the quality of groundwater for drinking purposes (Schulze et al. 2019).

Radioactive contaminants in groundwater can originate from geological deposits of radionuclides but also can originate from anthropogenic sources, such as wastes from nuclear power plants, nuclear weapons testing, and improper disposal of medical radioisotopes (Dahlgaard et al. 2004; Lytle et al. 2014; Huang et al. 2012). Radioactive substances can enter the human body through a variety of routes, including drinking water. However, radioactive contaminants have been rarely detected in groundwater at levels that are a threat to human health.

Biological contaminants include algae and microbial organisms, such as bacteria, viruses, and protozoa. For microbial contaminants, more than 400 kinds of bacteria have been identified in human and animal feces, and more than 100 kinds of viruses have been recognized (Shen and Gao 1995). Some of these microbial organisms originate from natural sources, but some include microscopic organisms that co-exist with natural algal species and compete for available resources (Flemming and Wuertz 2019; Lam et al. 2018). Drinking water contaminated by microbial contaminants can result in many human diseases, including serious diarrheal diseases, such as typhoid and cholera. Currently, the COVID-19 virus has resulted in pandemic affecting every corner of the world. This coronavirus is primarily transmitted from person-to-person through respiratory droplets (Centers for Disease Control and Prevention 2020). However, water contaminated by this virus also can threaten human health (Bhowmick et al. 2020; Lokhandwala and Gautam 2020). Algal contamination is very common in surface waters, such as lakes and 
reservoirs due to eutrophication, but algae are rarely found at a high biomass in groundwater.

\section{Consequences of Groundwater Contamination}

Groundwater contamination can impact human health, environmental quality, and socioeconomic development. For example, many studies have shown that high levels of fluoride, nitrate, metals, and persistent organic pollutants are a health risk for human populations (Wu et al. 2020). This is especially critical for infants and children who are more susceptible to the effects of these contaminants than adults (He et al. 2020b; Wu and Sun 2016; Karunanidhi et al. 2020; Mthembu et al. 2020; Ji et al. 2020; Subba Rao et al. 2020; Zhou et al. 2020). For example, "blue baby syndrome," also known as infant methemoglobinemia, is caused by excessive nitrate concentrations in the drinking water used to make baby formulas. Human health also can be affected by the groundwater contamination through effects on the food production system. Irrigation with groundwater contaminated by heavy metals and wastewater containing persistent contaminants can result in the accumulation of toxic elements in cereals and vegetables, causing health risks to humans (Jenifer and Jha 2018; Yuan et al. 2019; Njuguna et al. 2019).

Groundwater contamination also can negatively affect the quality of lands and forests. Contaminated groundwater can lead to soil contamination and degradation of land quality. For example, in many agricultural areas in arid regions, high groundwater salinity is one of the major factors influencing soil salinization (Wu et al. 2014). The soluble salts and other contaminants, such as toxic metals, can accumulate in the root zone, affecting vegetation growth. Groundwater contaminants also can be transported by surface watergroundwater interactions, leading to deterioration of surface water quality (Teng et al. 2018).

Sustainable economic development requires a balance between the rate of renewal of natural resources and human demand ( $\mathrm{Li}$ et al. 2017b). Freshwater is probably the most valuable of the natural resources. However, chronic groundwater contamination may reduce the availability of freshwater, breaking the balance between water supply and demand and leading to socioeconomic crises and even wars. Water shortages induced by contamination may become a factor causing conflicts among citizens in the future (Schillinger et al. 2020), possibly delaying the socioeconomic development of a nation. Groundwater contamination is not only an environmental issue but also a social issue, demanding collaboration between both natural scientists and social scientists.

\section{Articles in the Special Issue}

Nineteen papers are included in this special issue. The topics of these papers cover a range of contamination issues, including the sources of geogenic and anthropogenic contamination, seasonal cycles in contamination, human health risks, and remediation technologies. Figure 2 illustrates a word cloud generated using the words in the titles and abstracts of the articles in this special issue, showing the most frequently used terms. The word cloud shows that the most frequently used technical terms in the articles are water, risk, metals, nitrate, fluoride, polycyclic aromatic hydrocarbons (PAHs), health, limits, and values. These terms reflect the main topics of the articles, which cover the assessment of the concentrations of trace metals, fluoride, nitrate, PAHs, and other organic contaminants in groundwater and the associated risks to the health of human populations. Some more minor terms, such as geogenic, source, removal, statistical, EWQI, and mobility, indicate that some articles focus on evaluating the sources of groundwater contamination, approaches to groundwater quality assessment, and contaminant remediation techniques. The main contributions of each article in this special issue are summarized below.

Toxic metals are persistent contaminants and can be bioaccumulated in human tissues via food chain (He and Li 2020). In this special issue, six articles focused on the

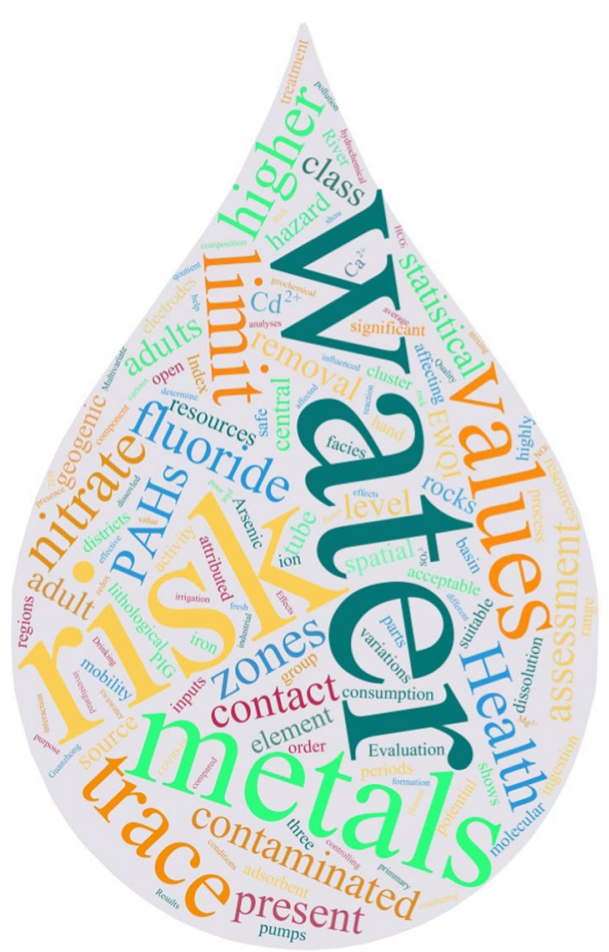

Fig. 2 Word cloud generated using the words in the titles and abstracts of articles in this special issue 
assessing trace metal pollution in groundwater. Çiner et al. (2021) used multivariate statistical analysis to identify the sources of trace elements in groundwater, including $\mathrm{Al}$, $\mathrm{Cr}, \mathrm{Mn}, \mathrm{Fe}, \mathrm{Co}, \mathrm{Ni}, \mathrm{Cu}, \mathrm{Zn}, \mathrm{As}, \mathrm{Se}$, and $\mathrm{Ba}$, and assessed the health risks from arsenic contamination in a region of south-central Turkey. Their research results indicate that the carcinogenic risks from exposure to arsenic to both adults and children were higher than the guideline limit, and the geogenic processes are the main cause of trace element contamination in groundwater in this region. Chandrasekar et al. (2021) also identified geogenic metal contamination in their article focused on the source, geochemical mobility, and health risks from trace metals in groundwater in a Cretaceous-Tertiary (K/T) contact region of India. However, Raja et al. (2021) concluded that industrial activities and leaching from municipal dumpsites were the main sources of the metal pollution in the groundwater in the industrialized township (Taluk) of Virudhunagar in India.

In addition to contamination of groundwater, trace elements can be transported via groundwater into surface waters and into oceans. In the article by Prakash et al. (2021), estimates were made of the submarine groundwater discharge and associated trace element fluxes from an urban estuary region to the marine environment in the Bay of Bengal in India. This study revealed that submarine groundwater discharge is an important factor contributing to the fluxes to the sea of dissolved trace elements.

Finding efficient and cost-effective technologies for removal of trace elements from groundwater is crucial for the sustainable management of water resources. Zhao et al. (2021) studied Cd removal from water using a novel low-temperature roasting technique associated with alkali to synthesize a high-performance adsorbent from coal fly ash. Dutta et al. (2021) proposed to use electrocoagulation with iron electrodes as a treatment technology for arsenic removal from groundwater, and a pilot scale filtration unit was used to remove ferric hydroxide flocs produced during the process.

Fluoride is of value in trace amounts for promoting dental health, but this anion is toxic when present in high concentrations in water and food (Adimalla and Li 2019; Li et al. 2014, 2019b; Marghade et al. 2020). In this special issue, two articles specifically address fluoride occurrence, distribution, and health risks. The article by Haji et al. (2021) describes a study of groundwater quality and human health risks from fluoride contamination in a region within the southern Main Ethiopian Rift. Keesari et al. (2021) used the empirical cumulative density function to estimate the health risks from consuming fluoride contaminated groundwater in northeastern parts of Rajasthan in India. These authors also produced a fluorosis risk map to aid decision makers in taking necessary remedial measures to improve the groundwater quality.
Organic pollutants, including polycyclic aromatic hydrocarbons (PAHs) and polychlorinated biphenyls (PCBs), are common contaminants of anthropogenic origin in groundwater that could cause serious health problems. In this special issue, two articles focused on these organic pollutants. The article by Ololade et al. (2021) reported an investigation into PAHs and PCBs in groundwater near selected waste dumpsites located in two southwestern states in Nigeria. They found that the more water-soluble, low molecular weight-PAHs accounted for more than $61 \%$ of the total PAHs detected across all locations, but surprisingly the more highly chlorinated hexa-PCBs dominated the congener profiles. In another paper in this issue by Ambade et al. (2021), the occurrence, distribution, health risk, and composition of 16 priority PAHs were investigated in drinking water from southern Jharkhand in the eastern part of India. These authors found that lower and middle molecular weight PAHs were dominant in groundwater from the study area, but the levels are currently below concentrations that are a carcinogenic risk.

Studies of radioactive elements in groundwater often are neglected, but these radionuclides can be a hazard to human health. Adithya et al. (2021) conducted a study in Tamil Nadu state in southern India to measure the levels of radon $(\mathrm{Rn})$ in groundwater and quantify the health risks. Their study showed that the $\mathrm{Rn}$ is released into groundwater from granitic and gneissic rocks within uranium-enriched lithological zones. However, the Rn levels determined in Bequerels per litre were lower than the guideline limit and the groundwater does not pose health risks to consumers.

In this special issue, Adimalla and Qian (2021) conducted a study on the spatial distribution and potential health risks from nitrate pollution in groundwater in southern India. The article revealed high nitrate levels in groundwater, at concentrations up to $130 \mathrm{mg} / \mathrm{L}$. Both adults and children were judged to face health risks from consumption of nitrate in drinking water, but children were identified as more susceptible to the effects of groundwater nitrate pollution. The paper by Karunanidhi et al. (2021) describes the improvements in groundwater quality that occurred in an industrialized region of southeastern India between January and June of 2020. These improvements included reduced nitrate contamination, which may have been due to reduced transport of nitrate into groundwater before the monsoon period, but also could have been due to the decline in industrial and agricultural activity in the region during the lockdown in India that began in March 2020 in response to the first wave of the COVID-19 pandemic. In this study, fluoride concentrations of geogenic origin also were lower in groundwater before the monsoon.

Understanding the seasonal and spatial variations in groundwater quality is essential for the protection of human health and to maintain the crop yields. Subba Rao et al. (2021) 
used multiple approaches to identify the seasonal variations in groundwater quality and revealed that the groundwater quality for drinking and irrigation purposes was lower in the postmonsoon period relative to the pre-monsoon period. The deterioration of groundwater quality in the post-monsoon period was attributed to contaminant transport occurring through groundwater recharge but also was influenced by topographical factors and human activities.

Understanding the hydrogeochemical processes affecting groundwater chemistry is the basis for effective management of groundwater resources. Ren et al. (2021) adopted statistical approaches and multivariate statistical analysis techniques to understand the hydrogeochemical processes affecting groundwater in the central part of the Guanzhong Basin, China. The main contribution of this article is that it could help local decision makers to make water management decisions in the densely populated river basin by providing them with useful groundwater management options.

There are four articles in this special issue that focus specifically on methods to assess groundwater quality and humfluoride and associated arsenicosis and fluoan health risks. Shukla and Saxena (2021) assessed the groundwater quality and health risk in the rural parts of Raebareli district in northern India. Wang et al. (2021) identified the hydrochemical characteristics of groundwater and assessed health risk to consumers in a part of the Ordos basin in China. Adimalla (2021) applied two indices: the entropy weighted water quality index (EWQI), and the pollution index of groundwater (PIG) to assess the suitability of groundwater for drinking purpose in the Telangana state in southeastern India. Khan et al. (2021) assessed the drinking water quality and potential health impacts by considering physicochemical parameters, as well as bacteriological contamination of groundwater in Bajaur, Pakistan.

Collectively, these articles contribute to the literature on scientific developments in the field of groundwater contamination. The case studies presented in these articles are useful for policy makers and the public to understand the current water quality status in these regions. In particular, these articles provide a window into the groundwater contamination issues that are affecting low- and middle-income countries and countries with emerging economies in the eastern hemisphere. Researchers from Europe, North America, and other high-income countries often do not grasp the extent of groundwater contamination from geogenic and anthropogenic sources in these regions and do not realize that many human populations have no choice but to consume the contaminated drinking water.

\section{The Way Ahead}

Groundwater contamination is now a global problem and the resolution of these problems requires close collaboration among researchers in universities and government agencies, industries, and decision makers from all levels of government. To solve the groundwater contamination problems, international collaboration is needed. This is particularly true in countries with developing economies where financial resources and access to advanced technologies are not readily available. Special focus should be given to the following aspects of research and training:

- Groundwater contamination issues in different countries should be addressed with a range of measures, techniques, and policies. Although groundwater contamination is a global problem, its nature and influencing factors are different between countries, climatic regions, and geological features. It may not be optimal to adopt remediation approaches that are successful in other countries or regions. For example, nitrate pollution is caused by fertilizer and manure applications in some agricultural regions (Zhang et al. 2018) but also may be caused by pollution by industrial and domestic wastewater in other areas, or even by explosives used in mineral exploration ( $\mathrm{Li}$ et al. 2018). It may be necessary to use different approaches to mitigate different types of nitrate pollution. Even in instances where fertilizer application is the common cause of nitrate pollution in a tropical and a temperate region, the remediation approaches could be different, as climate factors and soil characteristics will have a great influence on the mechanisms and extent of contaminant transport.

- With the rapid technological development, many novel techniques have been developed to study groundwater contamination, including geophysical and geoinformatics techniques. Geographical information systems (GIS) and remote sensing (Ahmed et al. 2020; AlAbadi et al. 2020; Alshayef et al. 2019; Kannan et al. 2019) have accelerated the development of groundwater science. In the future, artificial intelligence, "big data" analysis, drone surveys, and molecular and stable isotope analysis technologies will be more widely available for applications in groundwater research. Groundwater scientists need to adopt and apply these new technologies for the study of groundwater contamination.

- Governments, particularly in countries with developing economies need to invest in and encourage research and training in groundwater science. In many regions, human populations have no alternative but to consume groundwater that is contaminated with chemical or bio- 
logical agents, potentially causing wide ranging health effects. Investment is needed to determine the extent of this contamination and how to remediate the impacts on human health, or to find alternate sources of drinking water.

\begin{abstract}
Acknowledgements Editing a successful special issue is not easy. The Guest Editors must ensure that the topic is of importance and of broad interest so that there are an adequate number of contributors willing to submit their manuscripts. They must also make sure that the peer review process is efficient and effective, while maintaining the high quality of the papers. All of these cannot be fulfilled without the support of the Editor in Chief. So, we are extremely grateful for Prof. Chris Metcalfe's guidance and support for this special issue. We are also sincerely thankful to the reviewers who provided constructive comments that are essential for maintaining the high quality of the special issue. Last but not the least, the authors whose manuscripts were included and those whose manuscripts were rejected are acknowledged for their interest in contributing to the special issue. The special issue was edited in a situation in which the COVID-19 struck in nearly every corner of the world. We are impressed by the dedication of doctors who fought and/or are fighting against the coronavirus. Prof. Peiyue Li is grateful for the financial support granted by the National Natural Science Foundation of China (41761144059 and 42072286), the Fundamental Research Funds for the Central Universities of CHD (300102299301), the Fok Ying Tong Education Foundation (161098), and the Ten Thousand Talents Program (W03070125), which allow him to carry out various investigations. The year 2021 is the 70th anniversary of Chang' an University. Congratulations!
\end{abstract}

\section{Compliance with Ethical Standards}

Conflict of interest The authors declare no conflict of interest.

\section{References}

Abbas G, Murtaza B, Bibi I, Shahid M, Niazi NK, Khan MI, Amjad M, Hussain M, Natasha (2018) Arsenic uptake, toxicity, detoxification, and speciation in plants: physiological, biochemical, and molecular aspects. Int J Environ Res Public Health 15:59. https:// doi.org/10.3390/ijerph15010059

Adimalla N (2021) Application of entropy weighted water quality index (EWQI) and pollution index of groundwater (PIG) to assess the groundwater quality for drinking purposes: a case study. Arch Environ Contam Toxicol (this issue)

Adimalla N, Li P (2019) Occurrence, health risks and geochemical mechanisms of fluoride and nitrate in groundwater of the rockdominant semi-arid region, Telangana State, India. Hum Ecol Risk Assess 25:81-103

Adimalla N, Qian H (2021) Geospatial distribution and potential noncarcinogenic health risk assessment of nitrate contaminated groundwater in Southern India: a case study. Arch Environ Contam Toxicol (this issue). https://doi.org/10.1007/s00244-02000762-7

Adimalla N, Wu J (2019) Groundwater quality and associated health risks in a semi-arid region of south India: implication to sustainable groundwater management. Hum Ecol Risk Assess 25:191-216

Adithya VS, Chidambaram S, Prasanna MV, Venkatramanan S, Tirumalesh K, Thivya C, Thilagavathi R (2021) Health risk implication and spatial distribution of radon in groundwater along the lithological contact in south India. Arch Environ Contam Toxicol (this issue)

Ahmed A, Nawaz R, Woulds C, Drake F (2020) Influence of hydroclimatic factors on future coastal land susceptibility to erosion in Bangladesh: a geospatial modelling approach. J Geovis Spat Anal 4:6. https://doi.org/10.1007/s41651-020-00050-x

Al-Abadi AM, Ghalib HB, Al-Mohammdawi JA (2020) Delineation of groundwater recharge zones in Ali Al-Gharbi District, Southern Iraq using multi-criteria decision-making model and GIS. J Geovis Spat Anal 4:9. https://doi.org/10.1007/s41651-020-00054-7

Alshayef MS, Javed A, Mohammed AMB (2019) Appraisal of potential hydrocarbon zones in Masila Oil Field, Yemen. J Geovis Spat Anal 3:17. https://doi.org/10.1007/s41651-019-0043-0

Ambade B, Sethi SS, Kumar A, Sankar TK (2021) Health risk assessment, composition and distribution of polycyclic aromatic hydrocarbons (PAHs) in drinking water of southern Jharkhand, East India. Arch Environ Contam Toxicol (this issue)

Basu A, Saha D, Saha R, Ghosh T, Saha B (2014) A review on sources, toxicity and remediation technologies for removing arsenic from drinking water. Res Chem Intermediation 40:447-485

Bhowmick GD, Dhar D, Nath D, Ghangrekar MM, Banerjee R, Das S, Chatterjee J (2020) Coronavirus disease 2019 (COVID-19) outbreak: some serious consequences with urban and rural water cycle. NPJ Clean Water 3:32. https://doi.org/10.1038/s4154 5-020-0079-1

Centers for Disease Control and Prevention (2020) Global COVID19. https://www.cdc.gov/coronavirus/2019-ncov/global-covid-19/ index.html. Accessed 18 Oct 2020

Chakraborti D, Rahman MM, Mukherjee A, Alauddin M, Hassan M, Dutta RN, Pati S, Mukherjee SC, Roy S, Quamruzzman Q, Rahman M, Islam T, Sorif S, Selim Md, Islam MR, Hossain MM (2015) Groundwater arsenic contamination in Bangladesh-21 years of research. J Trace Elem Med Biol 31:237-248

Chandrasekar T, Keesari T, Gopalakrishnan G, Karuppannan S, Senapathi V, Sabarathinam C, Viswanathan PM (2021) Occurrence of heavy metals in groundwater along the lithological interface of $\mathrm{K} / \mathrm{T}$ boundary, peninsular India: a special focus on source, geochemical mobility and health risk. Arch Environ Contam Toxicol (this issue)

Çiner F, Sunkari ED, Şenbaş BA (2021) Geochemical and multivariate statistical evaluation of trace elements in groundwater of Niğde Municipality, South-Central Turkey: implications for arsenic contamination and human health risks assessment. Arch Environ Contam Toxicol (this issue). https://doi.org/10.1007/s0024 4-020-00759-2

Clement M, Meunie A (2010) Is inequality harmful for the environment? An empirical analysis applied to developing and transition countries. Rev Social Econ 68:223-232

Dahlgaard H, Eriksson M, Nielsen SP, Joensen HP (2004) Levels and trends of radioactive contaminants in the Greenland environment. Sci Total Environ 331:53-67

Dutta N, Haldar A, Gupta A (2021) Electrocoagulation for arsenic removal: field trials in West Bengal, India. Arch Environ Contam Toxicol (this issue)

Elumalai V, Nethononda VG, Manivannan V, Rajmohan N, Li P, Elango L (2020) Groundwater quality assessment and application of multivariate statistical analysis in Luvuvhu catchment, Limpopo, South Africa. J Afr Earth Sci 171:103967. https://doi. org/10.1016/j.jafrearsci.2020.103967

Flemming H, Wuertz S (2019) Bacteria and archaea on Earth and their abundance in biofilms. Nat Rev Microbiol 17:247-260

Goldhaber MB, Mills CT, Morrison JM, Stricker CA, Mushet DM, LaBaugh JW (2014) Hydrogeochemistry of prairie pothole region wetlands: role of long-term critical zone processes. Chem Geol 387:170-183. https://doi.org/10.1016/j.chemgeo.2014.08.023 
Government of Canada (2017) Groundwater contamination. https:// www.canada.ca/en/environment-climate-change/services/water -overview/pollution-causes-effects/groundwater-contamination. html. Accessed 17 Oct 2020

Gwenzi W, Chaukura N (2018) Organic contaminants in African aquatic systems: current knowledge, health risks, and future research directions. Sci Total Environ 619-620:1493-1514

Haji M, Karuppannan S, Qin D, Shube H, Kawo NS (2021) Potential human health risks due to fluoride contaminants of groundwater using multi-techniques approaches in Bilate River Basin of Southern Main Ethiopian Rift, Ethiopia. Arch Environ Contam Toxicol (this issue)

Hansen B, Thorling L, Schullehner J, Termansen M, Dalgaard T (2017) Groundwater nitrate response to sustainable nitrogen management. Sci Rep 7:8566. https://doi.org/10.1038/s41598-017-07147 $-2$

Hashim MA, Mukhopadhyay S, Sahu JN, Sengupta B (2011) Remediation technologies for heavy metal contaminated groundwater. J Environ Manag 92:2355-2388

Hayashi A, Akimoto K, Tomoda T, Kii M (2013) Global evaluation of the effects of agriculture and water management adaptations on the water-stressed population. Mitig Adapt Strateg Global Change 18:591-618

He X, Li P (2020) Surface water pollution in the middle Chinese Loess Plateau with special focus on hexavalent chromium $\left(\mathrm{Cr}^{6+}\right)$ : occurrence, sources and health risks. Expo Health 12:385-401. https:// doi.org/10.1007/s12403-020-00344-x

He S, Wu J (2019) Hydrogeochemical characteristics, groundwater quality and health risks from hexavalent chromium and nitrate in groundwater of Huanhe Formation in Wuqi County, northwest China. Expo Health 11:125-137

He X, Wu J, He S (2019) Hydrochemical characteristics and quality evaluation of groundwater in terms of health risks in Luohe aquifer in Wuqi County of the Chinese Loess Plateau, northwest China. Hum Ecol Risk Assess 25:32-51

He X, Li P, Wu J, Wei M, Ren X, Wang D (2020a) Poor groundwater quality and high potential health risks in the Datong Basin, northern China: research from published data. Environ Geochem Health. https://doi.org/10.1007/s10653-020-00520-7

He X, Li P, Ji Y, Wang Y, Su Z, Elumalai V (2020b) Groundwater arsenic and fluoride and associated arsenicosis and fluorosis in China: occurrence, distribution and management. Expo Health 12:355-368. https://doi.org/10.1007/s12403-020-00347-8

Huang C, Lin T, Chiao L, Chen H (2012) Characterization of radioactive contaminants and water treatment trials for the Taiwan Research Reactor's spent fuel pool. J Hazard Mater 233-234:140-147

International Association of Hydrogeologists (2020) Groundwatermore about the hidden resource. https://iah.org/education/gener al-public/groundwater-hidden-resource. Accessed 13 Nov 2020

Jenifer MA, Jha MK (2018) Comprehensive risk assessment of groundwater contamination in a weathered hard-rock aquifer system of India. J Clean Product 201:853-868

Ji Y, Wu J, Wang Y, Elumalai V, Subramani T (2020) Seasonal variation of drinking water quality and human health risk assessment in Hancheng City of Guanzhong Plain, China. Expo Health 12:469-485

Jurado A, Vàzquez-Suñé E, Carrera J, de Alda ML, Pujades E, Barceló D (2012) Emerging organic contaminants in groundwater in Spain: a review of sources, recent occurrence and fate in a European context. Sci Total Environ 440:82-94

Kannan R, Venkateswaran S, Vijay Prabhu M, Suresh R, Kalaiyarasi A (2019) Demarcation of groundwater possible zones in a hard rock terrain, Nagavathi watershed of Dharmapuri District, Tamil Nadu, India-Geophysical and geoinformatics approach. J Geovis Spat Anal 3:2. https://doi.org/10.1007/s41651-018-0025-7
Karunanidhi D, Aravinthasamy P, Subramani T, Wu J, Srinivasamoorthy K (2019) Potential health risk assessment for fluoride and nitrate contamination in hard rock aquifers of Shanmuganadhi River basin, South India. Hum Ecol Risk Assess 25:250-270

Karunanidhi D, Aravinthasamy P, Deepali M, Subramani T, Bellows BC, Li P (2020) Groundwater quality evolution based on geochemical modeling and aptness testing for ingestion using entropy water quality and total hazard indexes in an urbanindustrial area (Tiruppur) of Southern India. Environ Sci Pollut Res. https://doi.org/10.1007/s11356-020-10724-0

Karunanidhi D, Aravinthasamy P, Deepali M, Subramani T, Shankar K, Kumar M (2021) Groundwater pollution and human health risks in an industrialized region of southern India: impacts of the COVID-19 lockdown and the monsoon seasonal cycles. Arch Environ Contam Toxicol (this issue)

Keesari T, Pant D, Roy A, Sinha UK, Jaryal A, Singh M, Jain SK (2021) Fluoride geochemistry and exposure risk through groundwater sources in northeastern parts of Rajasthan, India. Arch Environ Contam Toxicol (this issue)

Khan MH, Nafees M, Muhammad N, Ullah U, Hussain R, Bilal M (2021) Assessment of drinking water sources for its quality, human health risks and pollution source(s) apportionment-a case study. Arch Environ Contam Toxicol (this issue)

Lam S, Nguyen-Viet H, Tuyet-Hanh TT, Nguyen-Mai H, Harper $S$ (2015) Evidence for public health risks of wastewater and excreta management practices in Southeast Asia: a scoping review. Int J Res Public Health 12:12855-12863

Lam TP, Lee T-M, Chen C-Y, Chang J-S (2018) Strategies to control biological contaminants during microalgal cultivation in open ponds. Bioresour Technol 252:180-187

Lapworth DJ, Baranm N, Stuartm ME, Ward RS (2012) Emerging organic contaminants in groundwater: a review of sources, fate and occurrence. Environ Pollut 163:287-303

Lapworth DJ, Baran N, Stuart ME, Manamsa K, Talbot J (2015) Persistent and emerging micro-organic contaminants in chalk groundwater of England and France. Environ Pollut 203:214-225

Lesser LE, Mora A, Moreau C, Mahlknecht J, Hernández-Antonio A, Ramírez AI, Barrios-Piña H (2018) Survey of 218 organic contaminants in groundwater derived from the world's largest untreated wastewater irrigation system: Mezquital Valley, Mexico. Chemosphere 198:510-521

Li P (2020) To make the water safer. Expo Health 12:337-342

Li P, Wu J (2019) Sustainable living with risks: meeting the challenges. Hum Ecol Risk Assess 25:1-10

Li P, Qian H, Wu J, Chen J, Zhang Y, Zhang H (2014) Occurrence and hydrogeochemistry of fluoride in shallow alluvial aquifer of Weihe River, China. Environ Earth Sci 71:3133-3145

Li P, Wu J, Qian H (2016) Preliminary assessment of hydraulic connectivity between river water and shallow groundwater and estimation of their transfer rate during dry season in the Shidi River, China. Environ Earth Sci 75:99. https://doi.org/10.1007/s1266 5-015-4949-7

Li P, Tian R, Xue C, Wu J (2017a) Progress, opportunities and key fields for groundwater quality research under the impacts of human activities in China with a special focus on western China. Environ Sci Pollut Res 24:13224-13234

Li P, Qian H, Zhou W (2017b) Finding harmony between the environment and humanity: an introduction to the thematic issue of the Silk Road. Environ Earth Sci 76:105. https://doi.org/10.1007/ s12665-017-6428-9

Li P, Wu J, Tian R, He S, He X, Xue C, Zhang K (2018) Geochemistry, hydraulic connectivity and quality appraisal of multilayered groundwater in the Hongdunzi coal mine, northwest China. Mine Water Environ 37:222-237

Li P, He X, Guo W (2019a) Spatial groundwater quality and potential health risks due to nitrate ingestion through drinking water: a case 
study in Yan'an City on the Loess Plateau of northwest China. Hum Ecol Risk Assess 25:11-31

Li P, He X, Li Y, Xiang G (2019b) Occurrence and health implication of fluoride in groundwater of Loess aquifer in the Chinese Loess Plateau: a case study of Tongchuan, northwest China. Expo Health 11(2):95-107. https://doi.org/10.1007/s12403-018-0278-x

Lin H (2010) Earth's critical zone and hydropedology: concepts, characteristics, and advances. Hydrol Earth Syst Sci 14:25-45

Lokhandwala S, Gautam P (2020) Indirect impact of COVID-19 on environment: a brief study in Indian context. Environ Res 188:109807. https://doi.org/10.1016/j.envres.2020.109807

Lytle DA, Sorg T, Wang L, Chen A (2014) The accumulation of radioactive contaminants in drinking water distribution systems. Water Res 50:396-407

MacDonald JA, Kavanaugh MC (1994) Restoring contaminated groundwater: An achievable goal? Environ Sci Technol 28(8):362A-368A

Marghade D, Malpe DB, Duraisamy K, Patil PD, Li P (2020) Hydrogeochemical evaluation, suitability, and health risk assessment of groundwater in the watershed of Godavari basin, Maharashtra, Central India. Environ Sci Pollut Res. https://doi.org/10.1007/ s11356-020-10032-7

Meffe R, Bustamante I (2014) Emerging organic contaminants in surface water and groundwater: a first overview of the situation in Italy. Sci Total Environ 481:280-295

Mthembu PP, Elumalai V, Brindha K, Li P (2020) Hydrogeochemical processes and trace metal contamination in groundwater: impact on human health in the Maputaland coastal aquifer, South Africa. Expo Health 12:403-426

Njuguna SM, Makokha VA, Yan X, Gituru RW, Wang Q, Wang J (2019) Health risk assessment by consumption of vegetables irrigated with reclaimed wastewater: a case study in Thika (Kenya). J Environ Manag 231:576-581

Ololade IA, Arogunrerin IA, Oladoja NA, Ololade OO, Alabi AB (2021) Concentrations and toxic equivalency of polycyclic aromatic hydrocarbons (PAHs) and polychlorinated biphenyl (PCB) congeners in groundwater around waste dumpsites in South-West Nigeria. Arch Environ Contam Toxicol (this issue)

Pandey HK, Duggal SK, Jamatia A (2016) Fluoride contamination of groundwater and its hydrological evolution in District Sonbhadra (U.P.) India. Proc Nat Acad Sci India Sect A Phys Sci 86:81-93

Prakash R, Srinivasamoorthy K, Sundarapandian SM, Nanthakumar C, Gopinath S, Saravanan K, Vinnarasi F (2021) Submarine groundwater discharge from an urban estuary to southeastern bay of Bengal, India: revealed by trace element fluxes. Arch Environ Contam Toxicol (this issue). https://doi.org/10.1007/s00244-020-00774-3

Raja V, Lakshmi RV, Sekar CP, Chidambaram S, Neelakantan MA (2021) Evaluation of human health risk assessment of heavy metals in groundwater of the industrial township of Virudhunagar, Tamilnadu, India. Arch Environ Contam Toxicol (this issue)

Rebelo FM, Caldas ED (2016) Arsenic, lead, mercury and cadmium: toxicity, levels in breast milk and the risks for breastfed infants. Environ Res 51:671-688

Ren X, Li P, He X, Su F, Elumalai V (2021) Hydrogeochemical processes affecting groundwater chemistry in the central part of the Guanzhong Basin, China. Environ Contam Toxicol (this issue). https://doi.org/10.1007/s00244-020-00772-5

Sawyer AH, Michael HA, Schroth AW (2016) From soil to sea: the role of groundwater in coastal critical zone processes. WIREs Water 3:706-726

Schillinger J, Özerol G, Güven-Griemert Ş, Heldeweg M (2020) Water in war: understanding the impacts of armed conflict on water resources and their management. WIREs Water 7:e1480. https:// doi.org/10.1002/wat2.1480

Schulze S, Zahn D, Montes R, Rodil R, Quintana JB, Knepper TP, Reemtsma T, Berger U (2019) Occurrence of emerging persistent and mobile organic contaminants in European water samples. Water Res 153:80-90

Serio F, Miglietta PP, Lamastra L, Ficocelli S, Intini F, De Leo F, De Donno A (2018) Groundwater nitrate contamination and agricultural land use: a grey water footprint perspective in Southern Apulia Region (Italy). Sci Total Environ 645:1425-1431

Shen J, Gao Y (1995) Groundwater and the environment. China University of Geoscience Press, Wuhan (in Chinese)

Shukla S, Saxena A (2021) Appraisal of groundwater quality with human health risk assessment in parts of Indo-Gangetic alluvial plain, North India. Arch Environ Contam Toxicol (this issue). https://doi.org/10.1007/s00244-020-00771-6

Sorensen JPR, Lapworth DJ, Nkhuwa DCW, Stuart ME, Gooddy DC, Bell RA, Chirwa M, Kabika J, Liemisa M, Chibesa M, Pedley S (2015) Emerging contaminants in urban groundwater sources in Africa. Water Res 72:51-63

Su Z, Wu J, He X, Elumalai V (2020) Temporal changes of groundwater quality within the groundwater depression cone and prediction of confined groundwater salinity using Grey Markov model in Yinchuan area of northwest China. Expo Health 12:447-468

Subba Rao N, Ravindra B, Wu J (2020) Geochemical and health risk evaluation of fluoride rich groundwater in Sattenapalle Region, Guntur district, Andhra Pradesh, India. Hum Ecol Risk Assess 26:2316-2348

Subba Rao N, Dinakar A, Kumari BK, Karunanidhi D, Kamalesh $\mathrm{T}$ (2021) Seasonal and spatial variation of groundwater quality vulnerable zones of Yellareddygudem watershed, Nalgonda district, Telangana State, India. Arch Environ Contam Toxicol (this issue). https://doi.org/10.1007/s00244-020-00783-2

Tatti F, Papini MP, Torretta V, Mancini G, Boni MR, Viotti P (2019) Experimental and numerical evaluation of groundwater circulation wells as a remediation technology for persistent, low permeability contaminant source zones. J Contam Hydrol 222:89-100

Teng Y, Hu B, Zheng J, Zhai Y, Zhu C (2018) Water quality responses to the interaction between surface water and groundwater along the Songhua River, NE China. Hydrogeol J 26:1591-1607

Wang D, Wang L, Yang Q, Yu K, Ma H (2021) Hydrogeochemistry assessment of shallow groundwater and its health threat on human in northwestern Ordos basin, China. Arch Environ Contam Toxicol (this issue)

Wang D, Wu J, Wang Y, Ji Y (2020) Finding high-quality groundwater resources to reduce the hydatidosis incidence in the Shiqu County of Sichuan Province, China: analysis, assessment, and management. Expo Health 12:307-322

Wu J, Li P, Qian H (2015) Hydrochemical characterization of drinking groundwater with special reference to fluoride in an arid area of China and the control of aquifer leakage on its concentrations. Environ Earth Sci 73:8575-8588

Wu J, Li P, Qian H, Fang Y (2014) Assessment of soil salinization based on a low-cost method and its influencing factors in a semi-arid agricultural area, northwest China. Environ Earth Sci 71(8):3465-3475. https://doi.org/10.1007/s12665-013-2736-x

Wu J, Sun Z (2016) Evaluation of shallow groundwater contamination and associated human health risk in an alluvial plain impacted by agricultural and industrial activities, mid-west China. Expo Health 8:311-329

Wu J, Zhang Y, Zhou H (2020) Groundwater chemistry and groundwater quality index incorporating health risk weighting in Dingbian County, Ordos basin of northwest China. Geochemistry 80(4):125607. https://doi.org/10.1016/j.chemer.2020.125607

Yuan Y, Xiang M, Liu C, Theng BKG (2019) Chronic impact of an accidental wastewater spill from a smelter, China: a study of health risk of heavy metal(loid)s via vegetable intake. Ecotoxicol Environ Saf 182:109401. https://doi.org/10.1016/j.ecoen v.2019.109401 
Zhang Y, Wu J, Xu B (2018) Human health risk assessment of groundwater nitrogen pollution in Jinghui canal irrigation area of the loess region, northwest China. Environ Earth Sci 77:273

Zhao H, Song F, Su F, Shen Y, Li P (2021) Removal of cadmium from contaminated groundwater using a novel silicon/aluminum nanomaterial: an experimental study. Arch Environ Contam Toxicol (this issue). https://doi.org/10.1007/s00244-020-00784-1
Zhou Y, Li P, Chen M, Dong Z, Lu C (2020) Groundwater quality for potable and irrigation uses and associated health risk in southern part of Gu' an County, North China Plain. Environ Geochem Health. https://doi.org/10.1007/s10653-020-00553-y 